\title{
Cultural Transformations into Tourist Attraction
}

\author{
Arief Faizal Rachman ${ }^{1 *}$, Y.C. Tekol ${ }^{2}$ \\ ${ }^{1}$ Department of Tour and Travel, Sekolah Tinggi Pariwisata Trisakti, South Jakarta, Indonesia \\ ${ }^{2}$ Bawah Reserve, Anambas, Riau Kepulauan Province, 29791, Indonesia
}

\begin{abstract}
Marine-based culture performed social construction where local belief dominated and influenced daily basis culture. Selamatan Laut ritual was a sacred event where collecting spiritual power led by shamans. The focus of the research was to examine the cultural transformation of the ritual into a tourist attraction. In-depth interviews with seven members of the local community and a visitor enabled the researchers to explore the ritual practice. Analysis of the data revealed that the ritual was also scheduled cultural event calendar as a tourist attraction. The event attracted more tourists to grab income for locals and the region itself.There were physics and function cultural transformation at the ritual ceremony. The physical transformation included the establishment of tourist facilities. Meanwhile, functional transformation included the relation between actors in the community.Both physical and functional transformation relation created new social structures in the community. Local government dominantly played as an agent of change at the site. Local's community perceived the transformation of the event created new tourist attraction in Manggar, where scheduled events were being as a consensus between stakeholders.
\end{abstract}

Keywords: cultural tourism, ritual, tourist attraction, transformation.

\section{INTRODUCTION}

One of the cultures in Manggar, Bangka Belitung is a ritual in the form of selamatan laut, which commonly referred to as sea salvation. The ritual was an adaptation of the customary rituals of sea tribes or Sawang tribes, called Buang Jong. Dispose of Jong comes from two syllables, Buang means to throw away, and Jong means boat. In other words, Buang Jong or the selamatan laut ritual means to float Jong's (boat) into the sea, the small boat was in the form of a frame, which contains offerings. In general, the purpose of this ritual was to refuse reinforcements or distress, express gratitude for the fortune given by God Almighty, and ask for safety for the fishermen and their families. Therefore, in fulfilling their daily duties as fishermen, they won't get any interference, so that they get results lots of fish catch. This event was held once a year around the coast in East Belitung Regency.

Days before the selamatan laut ritual began, the fisherman community made a contribution to support this ritual. Then, seeing the persistence of the fishing community, the local government also contributed to the budget. The benefits that can be gleaned from the ritual were mutual care for fellow fishermen, mutual cooperation culture, inviting people to maintain their relationship with the surrounding environment, encouraging

\footnotetext{
* Corespondence Address:

Arief Faizal Rachman

Email : arief@stptrisakti.ac.id

Address : Sekolah Tinggi Pariwisata Trisakti, JI. IKPN-Tanah Kusir-Bintaro, South Jakarta, 12330, Indonesia
}

community morale to think openly by preserving the traditional culture of the Village.

Cultures were also constructed by three main types of religion, based on very different beliefs, traditions, and codes of behavior [1]. Selamatan laut ritual was a part of a culture where the element of belief dominantly influenced. There was a significant willingness of communication between humans and God, especially while bad luck, calamity, and disaster happened to the human being.

The social construction of the ritual was related to local stakeholders, fishermen family (as a victim), shaman of sea and shaman of village, communities, and local authorities. On the ritual as a part of a culture, a social construction where people communicate to the invisible creature, named Antu Laot (the ghost of the sea). By using Bonnemaison's work of four pillars of culture, included; knowledge, technique, belief, and space, [2] argued the culture is not always something traditional (in wine tourism); it is because of human activities on a landscape of wine plantation.

Another researcher [3] after his work in Mojokuto, Java Island, named this kind of ritual as a Slamatan. Furthermore [3] classified the invisible creature (ghost) those live surrounding human as amemedi (frightening spirit), lelembut (possessing spirit), tujul (familiar spirit), demits (place spirit), and danjangs (guardian spirit). When the ritual was held, there were offerings in form of flowers, black chicken, foods, and small house or vehicle as a symbol of residence of the spirits. Meanwhile, the ritual in Manggar used 
boat replica in small size (jong) to worship the Antulaut (the ghost of the sea). The jong also was fulfilled by offerings such as flowers, foods, and others.

Ritual in eastern culture (Bali case) mostly had a deeply religious purpose, in the occasion of purification ceremony, the passage for the innocent, duty-bound and vulnerable adult, and goals to purify and provide a human being into appropriate spiritual power to exist peacefully, productively, and healthfully in a dangerous world [4]. Rituals were also part of daily life for Balinese people, with the philosophy way of life Tri Hita Karana (The three causes in achieving well being and prosperity for humanity). The three elements are united with each other, but at present, global tourism influenced to purity and authenticity of Balinese culture.

Coastal and beach-based communities had strong relation with sea weather and the number of fishing. Lack of fishing and incident of the fisherman (even to the death) caused by bad weather will be symbolized by locals as bad luck or anger of ghosts of the sea (Antu Laot). Different cultural geography expressed people's identity at the destination, such as dances, traditional songs, and other performance [1], and also the selling of destination [5]. The study of geography included human geography that was specifically related to local communities' identity and daily life, called culture. The local culture was not only on cultural performance, but it produced believes.

Cultural tourism focused on tourism experiences and specific forms of cultural tourism, and sites to be visited by tourists could be buildings and daily life of people at the destination [6]. The traveler or tourists will experience a different space and interaction compared at daily activities at home. Experiences included time arrangement, highlight of visitation, and memories that will be taken at home, even souvenirs as a sign of visitation. In travel experiences in a scared ritual in a community, tourist will perceive a locally respect and even as a part of tradition for locals Reversely, it is something irrational for the visitor who came from modern education.

Cultural tourism was also called as ethnic tourism, while these ethnic representations were the important elements for cultural development [7]. The two most important components in developing tourist destinations are nature and culture aspects. Mother Nature was a given to human being in the world, but the culture was not a given, it was dynamics aspect at any time and places. The culture had strong dynamics by people who have a variety of characters. Furthermore, development needs period time of process, tools, and equipment (technology) and acceptance of people (culture).

The cultural landscape was also part of tourism destination where people and land have their own characteristic [8] and land use for wine agritourism [2]. The landscape of people in Manggar where the ritual held was a coastal area, so the local community at the destination mostly a marine-based community. Another region of a cultural landscape that was recognized as a world heritage is Subak in Bali, which became a famous tourist attraction. However, it was still threatened by the transformation of land use for the tourism business.

Social valuing on local culture on a community contested when there were interactions between people (host and guest) and tourism spatial itself. The phenomenon of tourism revealed physical, mental, and spiritual attachments which appropriate to the daily basis of locals. Furthermore, a past time data on a community was called a tradition, cultural identities (present) and cultural aspiration (future) [9]. Other value related tourist attractions were value in education, culture, and pride where locals will examine themselves, especially when it applied in the tourism industry, called tourist attraction value.

There was a transformation when cultural and tourism met face to face into a cultural tourism product [7]. Transformation at tourist destination directed to physical and functional transformation, where physical transformation revealed development of facilities and infrastructure.

Meanwhile, functional transformation included local people empowerment and capacity building. The social transformation also included the shape of the artifacts because there were no boundaries between social and technical agents. Researchers assumed the actor-network theory will explain materially and discursively, the enactment of heterogeneous relations that create all kinds of agents, including objects, subjects, human beings, machines, animals, nature, ideas, organizations, inequalities, scale and sizes, and geographical arrangements [10].

The research problems were transformation when stakeholders put the ritual into one of the tourist attractions in Manggar. They tried to 
minimize the lack of information to many visitors about the ritual, considering this event is not a permanent event that carried out scheduled with the same date every year. This event was held to refuse reinforcements, and when weather conditions were uncertain, waves in the sea were fierce, or accidents happened to fishermen. When the ritual took into atourist attraction in Manggar, there will be transformations within the community, and it will be examined in the research.

Manggar is a new developing tourist destination in East Belitung Regency, Belitung Island, Indonesia. As a small town, it was well-known for tin mining in the 1970s, and tin mining once became a main natural resource production. Most people in the town who worked in tin mining then created a new culture of free time after working called ngopi (coffee time), created lots of coffee shops in the town. But the golden era of tin mining came the end after lacks of production and fall of tin price in the world.

Nowadays, remain of coffee shop tradition still can be seen, and the town gets the nickname as Thousand Coffee shop Town. It is a changed of socio-economics, where the coffee shop put as a tourist attraction for visitors, and tin mining became one of the historical tourist attractions in the town. Meanwhile, the beautiful beach is a natural tourist attraction along the region. Most visitors only came to Manggar for transit and had lunchtime before they proceed to other regions, and the bus group tour did not make a night stop in Manggar on the itineraries.

Local tourism authority attempts to create other tourist attraction to get more tourists to visit and stay longer in Manggar. The selamatan laut ritual has the potential as an attraction. But it has not promoted yet by the local tourism authority as a permanent calendar event due its unpredictable schedule. It depended on the spiritual guidance of sea ancestor, which translated by sea shaman. Therefore, aims of the study were to determine the actors related to selamatan laut ritual who constructed the structure of event, the relation between actors created social value transformation that occurs when the tourism introduced into an activity of culture through a selamatan laut ritual in Manggar, and the transformation into a tourist attraction in the community means the selamatan laut ritual adjusted to be a permanent calendar event.

\section{MATERIAL AND METHOD}

When overview theory suggested, this is a socio-cultural research, a qualitative method used to examine the contested value between locals. It is important to understand contested social and technical value at the destination because social and technical values were the object of transformation. Authenticity value will transform into new perceptions of locals, which lead to tourist attraction value [11].

\section{Data Collection \\ Participants}

Both researchers had observed in the area for six months and found suitable participants for the research. All participants are residents of Manggar that have a variety of age, gender, occupation and living arrangements. Participants range from 25-60 years in age. A total of three women and six men were interviewed, and all of them married with children. The biographical profile can be seen in Table 1 . It is important to examine individuals from local area in a different social group and class.

\section{Interviews}

An in-depth semi-structured interview guide was designed, and respondents were individually asked open-ended question, based on the review of literature. Qualitative research used to address a number of different types of objectives in the research process [12]. Another researcher conducted in a small number of participants, sometimes it is in informal situations, and taperecorded [13].

\section{Data Analysis}

It used descriptive methods to facilitate researchers in determining the unit of analysis, the type of data used, methods of data collection, analysis, and desired output in this study. The results of the interviews will be discussed and analyzed as a result of the research. The analysis process begins with the identification of the social group associated with social value, then transformation after tourism was introduced in Baru Village, Manggar Town. After using the snowball method in the determination of social groups are involved, and then discovered several groups of stakeholders at the location social groups identified as directly involved with the transformation. 
Table 1. Biographical profile of respondents

\begin{tabular}{|c|c|}
\hline Respondents & Description \\
\hline $\begin{array}{l}\text { Informant } 1 / \text { Female/40 years old/ Secretary of } \\
\text { Baru Village }\end{array}$ & $\begin{array}{l}\text { Supporting a traditional event through village policy and funds, } \\
\text { especially transformation into a tourist attraction. }\end{array}$ \\
\hline $\begin{array}{l}\text { Informant } 2 / \text { Male/50 years old/Head of Sub- } \\
\text { village }\end{array}$ & $\begin{array}{l}\text { People had changed, they were not afraid of AntuLaot (sea ghost), they } \\
\text { were afraid of the crocodile. But as locals, it is a pride to get involved } \\
\text { with the ritual. It is the potential to be cultural tourism. }\end{array}$ \\
\hline $\begin{array}{l}\text { Informant } 3 / \text { Male/ } 30 \text { years old/ Tourism and } \\
\text { Culture Authority staff }\end{array}$ & $\begin{array}{l}\text { The ritual was held for the goodness of fishermen and preservation of } \\
\text { the culture. Through the policy of tourism, it will make selamatan laut } \\
\text { ritual as a tourist event calendar in the region. }\end{array}$ \\
\hline Informant 4/Male/65 years old/shaman of village & $\begin{array}{l}\text { Appreciation to local wisdom while most local communities are Muslim } \\
\text { followers. It is a pleasure if the ritual became a tourist attraction. }\end{array}$ \\
\hline Informant 5/male/ 67 years old/shaman of the sea & $\begin{array}{l}\text { Keep communicating with the unseen entity in the sea for the safety of } \\
\text { fishermen. The ritual must be held annually by the communities. It is an } \\
\text { honor for people here if there are visitors from other islands. }\end{array}$ \\
\hline Informant $6 /$ male/ 30 years old/fisherman & $\begin{array}{l}\text { A continuum of ancestor tradition, to protect fishermen from bad luck } \\
\text { when they were fishing. }\end{array}$ \\
\hline Informant $7 /$ male/70 years old/fisherman & The village was ready to welcome visitors when the ritual will be held. \\
\hline Informant $8 /$ female/20 years old/visitors & $\begin{array}{l}\text { It is a sacred ritual that will attract people to see in various motives. It is } \\
\text { a potential tourist attraction. It should be supported by tourism facilities } \\
\text { at the area and hospitality and tourism education for locals. }\end{array}$ \\
\hline
\end{tabular}

\section{RESULT AND DISCUSSION Selamatan Laut Ritual}

All data collected showed that selamatan laut ritual remained an authentic tradition for many respondents because they still set the function as safety and security, and welfare for fisherman village. However, the findings also highlighted how the process of ritual transforms into tourist attraction occasion as it is potential cultural resources for tourism in the region. The occasion of the ritual was only for protecting the fisherman from the evil spirit of Antu Laot (sea of the ghost) and also for welfare of the community. It also created a social structure for the authenticity of the ritual before tourism influenced it. Respondents were asked about the contents of rituals, the relation between stakeholders at the event, and their perception of the transformation of ritual into cultural tourism.

"We like it; we can continue what is done by our ancestors for our safety at sea. We are the fishermen who also helped from the beginning of the contribution to the process of dissolving it." (Informant 6)

Selamatan laut ritual was originally is a sacred tradition held by local communities of Sawang tribe. Because of its uniqueness and were able to attract visitors, the local government set the ritual as a tourist attraction. Host and guest relations triggered a transformation in selamatan laut ritual at Manggar. The local government viewed that guest activity by visiting, interacting, and spending money at the location will be an advantage for the region.
Manggar as a tourist destination was developed in facilities, infrastructures, transportation, and hospitality of local people. It included an effort to set a sacred ritual of selamatan laut ritual as a tourist attraction. Transformations of an institution (government, business, and local society) at tourism destination were modified and arranged [14].

The celebration of the ritual was modified by local tourism authorities as a tourist attraction. Transformations impacted the physical and cultural aspects of rural area [15]. The impacts on local society are on social and cultural. On social and cultural impacts, respondents were encouraged to recall daily basis interaction and also for the special occasion of the ritual. The selamatan laut ritual as a tourist attraction has significant meaning in the fishing sustained ritual society in Manggar. People believed that the ritual can be used as a means to give thanks, prayed for requests for salvation and protection, and established close relations with God, the ancestors and subtle spirits of the seas.

The tradition from the ancestor acted as the main idea of cultural value. This ritual inherited from ancestors, which were still being sustained by the support of cultural innovation by a community-based and environmental-based tourism approach.

"Selamatan laut ritual is a local culture of their belief in coastal village communities. The meaning of the ritual is to strive for safety for the fishermen who go to sea, to refuse reinforcements if there is a disaster, and to maintain human closeness with the metaphysical creatures of the sea. " (Informant 3) 
"Mother Nature, as part of life, is keeping them to be patient, and respecting nature. It encourages them to perform sea rituals as a means of communication. The custom that carried out in the remote area, in other parts of the coastal area, refuses reinforcements and hopes, as well as at the same time when going to sea." (Informant 5)

\section{Transformations in Culture of Selamatan Laut}

The rural area at any geography had its character culture, including marine-based culture in Manggar. A village where cultural resources occurred as a destination, potentially to be an outdoor ethnographic museum, furthermore, a theme park is an example of it [16].

Transformations in culture as a tourist attraction were studied by many scholars recently. It focused on the interaction and its impact on each other, both to culture and tourism. The culture of the local community was influenced by geography, whether the local community that lives in the area of mountainous, beach or urban and rural areas [2]. Culture could transform an identity of people and often put as a product of tourism, which demography factors influenced the cultural products. Even traditional ceremonies for worshipping the ancestors aligned to be tourism products [17], cultural behavior tranformed into attraction [18], and sacred ritual changed into more commercial with tour package [19]. Transformation blended between tourism and traditional culture, into economy dualism and cultural involution [20].

The value of religious education was a viewpoint that binds humans to the creator of nature and everything in it. The value of religious education in the ritual aims to make people undergo activities in life based on religion. Religion was a deep awareness of the depths of the human day as human nature. The ritual was inseparable from the ritual activities of the ancestral community of fishermen. This activity was once deeply related to their religion. They know exactly which one is not allowed in this ritual.

"When we want to hold the selamatan laut ritual, we actually refuse, because it is against religion, seeing the ancient times the rituals are only the sea shaman who goes through. Now, with some considerations, one of them promotes Manggar tourism. We try to support what is planned by the fishing community." (Informant 1)

Belief as one of the cultural elements pushed the local community to communicate to their spirit, to God Almighty or ancestor in selamatan laut ritual. Transformations in celebration of spiritual communication into tourist attractions were constructed by certain events and occasions. In Bali, lively cultural attraction such as the birth of a baby, circumcision, adolescence, marriage, having children, welfare, bad and good luck destiny, and the funeral ceremony held to build a spiritual fulfillment, not only a physical needs [4]. It was an auto poetic process, while indigenous people did not realize they were being watched by visitors.

In the case of Toraja's funeral [21] and Bali cremation ceremony [22], the duration of the ceremony even took one to seven nights and spent hundreds of millions rupiah, where transformed funeral ceremony seemed to be a thanksgiving day party. Belief, or sometimes it was called religion, had a symbolic meaning of obedience to followers.

Fishermen's belief in mystical matters is related to their social culture. The implementation of the selamatan laut ritual was a tradition carried out by the fishing community for generations. They carry out this tradition together. The existence of natural phenomena and the strength of the ghoib (invisible creature) was the basis for the implementation of the traditional ceremonies of the ritual.

\footnotetext{
"Just mentioning Antulaot (the ghost of the sea), the name was never known. I just called him, and then he came. But, if anyone wants to really study, then I introduce them." (Informant 5)

"That is proof because we have not held a selamatan laut ritual for a long time. We were struck by a calamity, some fishermen got sea accident and lost, their bodies have not been found for a long time." (Informant 7)
}

Another source explained the truth of the folklore about the Antulaot (ghost of the sea) myth. However, the story or name was not told by Informant 5 (the sea shaman). He insisted not to provide any information about the AntuLaot myth. Except, if anyone is willing to be serious about studying it with him, and wanted to be a successor to have a special ritual. If anyone wants to be his successor, he would personally introduce him/her to the Antu Laot. The obedience of followers conceptualized into the dimension of spiritual, social, environments, and more economic value in the transformations.

Spatial and people could not be separated. It increases the characters of man and place, culture, and economy [23]. These three dimensions in Bali constructed a social relation to 
be chosen as Cultural Landscape World Heritage Site [24], where additional highlight culture transformed into a worldwide level tourist destination.

A source explained that many opinions were emerging. Therefore, there was a need for tolerance among people. However, we also have to have a separate position, knowing what was right and not. This action was needed to evaluate community morals; the goal was to improve selfquality and community.

"According to their belief, Antu Laot (the ghost of the sea) was going to land. Yes, we listen to a story just like that. (We) need to be tolerant; the trust of different people is the responsibility of God." (Informant 1)

"I did not take part in the implementation. But, I still come to participate." (Informant 4)

\section{Selamatan Laut Ritual as Tourist Attraction}

The occasion of selamatan laut ritual, in the beginning, was only for salvation after a calamity that caused of the death to the fisherman. The ritual was not a daily cultural performance, neither scheduled program, nor as an event calendar. Transformations in the concept of culture appeared when the ritual put in an event calendar of regional tourism.

Balinese culture had its own lunar calendar, named Pakuwon, where it provided the references system all rituals in Bali, as well as market days, temple and personal anniversaries, good and bad luck days and also for doing special occasions [4]. Javanese showed a year lunar calendar where rituals were held for 1 ) life cycle ofhuman-birth, circumcision, marriage, and death; 2) Muslim ceremonial; 3) social integration of village, such as Bersih Desa (village cleaning activity), cleansing the village from evil spirit; and 4) irregular interval and unusual occurrences [3].

Selamatan laut ritual classified as cleansing the sea from evil spirits where it was only held on bad weather sea or even caused the death of fishermen. The bad sea weather and death were a marker for the reason why they had to do the ritual and transformed into a tourist attraction. Then the phenomenon about the shaman of the sea as the leader of the ritual (Informant 5), is someone who is believed to be a follower of the strata guru shaman, the shaman who still adheres to his beliefs in the spirits.

\begin{abstract}
"I also continue to pray to the Almighty. By the will of Allah, I beg to get the power to speak with Antu Laot. But, because of this inheritance from the ancestors, I also continue to live it. "(Informant 5)

"I do not spell the ancestors' mantras. I only pray to Allah. However, I still visit the ceremony." (Informant 4)
\end{abstract}

Dualisms contested on the ritual, a binary opposite [25] that constructed a leader of the ritual. The selamatan laut ritual was led by two men who had spiritual power to communicate with the ghost of the sea creature (antu laot), namely dukun laut (sea shaman) and dukun kampong (village shaman). As the ritual contested in tourism purposes, the transformations of shaman function were to set dates and days arrangement of the ritual. Dates and days arrangement was taken from the spiritual guidance of the ancestors.

The result of spiritual guidance was not only delivered to local community organizers, but it will be informed to local tourism authorities as promotional materials and published in some promotional media. The transformations were in the form of mass communication, locals to formal printed information. At the same time, dukun kampong covered the ritual by communicating to God Almighty in the Muslim way, where non-linearity created between communities. As it was a non-linearity transformations network pattern [26].

The fishing community in the village performed a sense of responsibility for the traditions they have. They felt that the ritual brings blessings to their lives, so they must be maintained. The value of responsibility was illustrated by the preservation of nature.

\footnotetext{
"The fishing communities are not alone, everything is negotiated together. Some local officials help contribute, and when we do it, we ask for cooperation from every stakeholder in the village."(Informant 2)
}

Every implementation of cultural activities always had a historical setting, as well as the ritual. The implementation of this tradition could not be separated from history.

"I actually don't understand the history. My father was a man of antiquity who taught me hard. So we don't dare ask it. It is just that we know, we are indeed descendants of my great-grandfather, my fourth-great-grandfather. "(Informant 5)

The social structure was shaped on a community where individual and community was in a concrete relationship, and there were 
interactions among collaborative social activity [27]. This relationship also included the selamatan laut ritual. The existence of shamans, fisherman, local authorities, local communities, the Sawang tribe dancer, visitors, bad weather, and miniature of boat (jong) was constructed and related to it. As social actors on the structure of the two shamans' related to a leading pray procession [3], the fishermen hope they would be safe and earned a lot of fish catching. Local tourism authorities permitted a three-day ritual procession and participate in the program. Local communities visit the ritual while there were some taboos before and after the ritual. The Sawang dancers were honored because their culture were performed, and visitors respected the ritual and satisfied by the cultural event [28].

Other sources explained that they were so proud to see the ritual preservation efforts supported by various parties ranging from the fishing community, law enforcement, village authority, and contributions from local officials who live in the village. It showed that the ritual is a means to get closer and build cooperation in community life.

"The implementation went well. We prepared fishermen, as well as joint ventures for each owner. The smallholder is charged IDR 50,000 and a large one for IDR 100,000." (Informant 7)

"We try to support the plan from the fisherman community by funding." (Informant 1)

Transformations relation also constructed the economic side, how they fund the event, especially the transformation of ritual into celebrating an event. Funding was gathered by collecting money from locals and local government. Transformations were defined (temporary) by social entrepreneurship (SE) relations and created in local social movement [29]. Visitors and local tourism authorities are actors that constructed while tourism came to the idea as part of the culture of locals.

Meanwhile, technical actors such jong (boat miniature) and its offering were launched to the sea to protect fishermen and people from worst calamity of bad weather. Establishing tourism facilities such as gallery for tourism information center, restaurant area, signboard of Sapta Pesona (Indonesia tourism philosophy campaign), and pathway at the area of the ritual was symbolic of transformations in the ritual. The power of relationships between agents (social and technical) was constructed in heterogeneous relations that create and reshuffle the agents, including the ghost of the sea, offerings, boat, and geographical arrangements [10]. Power relation was created in a social movement where the relation between individual level, organization, and event [29].

Additional events in this ritual in various tourism villages of East Belitung Regency are varied. Local communities invited people from the Sawang tribe, Gantung to bring the art of Campak Laut dance. It was in line with the statement from the Head of the Village.

"We invited the Campak Laut dancer from the Sawang tribe; this traditional event became a tourist attraction." (Informant 7).

\section{The Value of Selamatan Laut Ritual}

Preservation of the Selamatan Laut ritual as a cultural tourist attraction in East Belitung Regency was the responsibility of the entire local community of the village. The implementation involves the intervention of many parties ranging from preparation, implementation to the completion of the event. The ritual contains a value of pride that is assisted by cooperation from various parties, starting from the fishing community, traditional leaders, the local authorities (both tourism and government).

"I am happy that the Selamatan Laut ritual has been carried out with supported by the village authority, some volunteers and donation came from local officials and accepted by the community, visitors, and students." (Informant 5)

Selamatan Laut in Manggar has a social structure of ritual, both for social and technical actors [10], then it created social values transformations, which contained physical, mental, and spiritual attachment in the field of community [9]. On Selamatan Laut ritual, there were values during three-day of ritual celebration (pre, during and post ritual). On pre-ritual, there were values of social relationships (mental context) between the local community and stakeholders. The community felt the same sense of calamity of sea accident and bad weather during the monsoon (physical context) and strongly related to social value for managing the environment [30].

Physical context also related to preparation for the event, included stage decoration, supplies for the event, invitation, jitun (pole), and the most important physical context was the miniature of boat (jong) as a sacred artifact of the event. They need to overcome the situation by taking a ritual (spiritual context). The Selamatan Laut ritual took the symbol of 
economic transformations value when they collected funding to run the ritual as [29] stated about social entrepreneurship at the community, also for the advantage of the region as a tourist destination.

Respondents were asked about the identity of their community. One value of pride in the marine life of the Village was to maintain the authenticity of the local wisdom of the community. It means a form of support, maintenance of regional culture, and increasing community participation in organizing Selamatan Laut rituals as an authentic local coastal culture.

\footnotetext{
"For the ritual and jong remains the same. The difference is in the variation of jong shapes, offerings, and additional events for community entertainment." (Informant 5)

"After the ritual was held, then the program continued with enjoying a meal in the form of catches from the water of Gusong Cine. But previously, various messages from the Shaman Village were conveyed to the public who invited to respect the sea. Lunchon at that time was conducted in the traditional way, namely Makan (meals) Bedulang. "(East Belitung Culture and Tourism Office Article)
}

During the three-day Selamatan Laut ritual [31], the context of values related to the spiritual dimension. Spiritual as a value [9], was constructed when Selamatan Laut ritual became the media for communication to their ancestors, antu laot (myths of the ghost of the sea) and God Almighty. On the first day (started on Friday), symbolic of communication through mantras were spelled by sea shaman for the ancestors to have guidance for kind of woods as materials to make jong (boat miniature), ancak (home miniature and jitun (pole), where these artifacts contained physical dimension [10]. In the night, spiritual value of shaman communicates to spiritual ancestors, held to inform that jong (boat miniature) was ready to launch.

On the second day (Saturday), spiritual communication by sea shaman spelled the mantras for the welfare of fishermen and all dances and offerings dedicated to worshiping the spirit of ancestors. The third day (Sunday) was the highlight of the ritual, where jong (boat miniature as an offering) launched in the middle of the sea led by sea shaman (Fig.1). It followed by participants, visitors (to see the procession), and local tourism authority (for documenting the event) as it set to be a calendar event. Three-day ritual documentation and attended by visitors were a form of transformations in function.

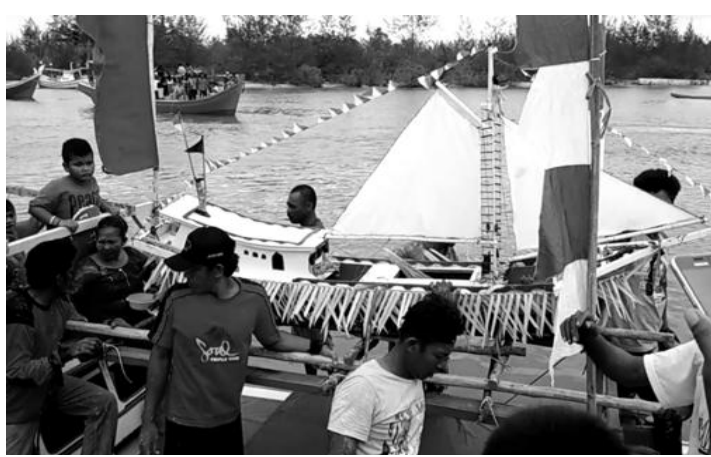

Figure 1. Selamatan Laut ritual, where jong (boat miniature) launched to the sea, Manggar Town.

Based on the results of the interview above, the first informant expressed his pride in organizing the ritual. It is due to the welcome from various parties who came to enliven so well. The participant also experienced acculturation between culture and religion, so the progress of the implementation was better than before.

"Insha Allah (God willing), next year's implementation will begin with tourism promotions. At the moment, we are trying to establish and confirm the village boundaries in advance as a support for the plan for indications of Tourism in Baru Village." (Informant 1)

On post-ritual, values of obedience to ritual procession were still followed by local communities, such as marking on their forehead by lime betel and washed their face to avoid bad luck. The sea shaman still maintained the ritual procession until the night, where there was others communication between shaman with the spirits' of the ancestors that confirmed the jong (boat miniature) was already received by the spirits of sea ancestors [31]. The ritual values were held for the good luck of individuals, between individuals and organizations, where social value staged at three-level [32], ], now transformed into a tourism-purposed organization at Manggar town.

\section{Tourism Education of Selamatan Laut}

All coastal villages in East Belitung Regency carry out the selamatanlaut ritual as a form of tourism education on local cultural tradition. However, its implementation has never been properly promoted.

"This ritual has the potential to be a cultural tourist attraction because there is a unique attraction that is the selling power. But because this is the first time we have held it again, the notification of this event is only limited to neighboring villages." (Informant 1) 
"I am happy; there was a positive response from visitors who said that this was a new experience for them and the characteristics of our village." (Informant 5).

"It is a sacred ritual that will attract people to see in various motives. It is a potential tourist attraction. I like to talk with the locals. They are kind people. It should be supported by tourism facilities at the area and hospitality and tourism education for locals." (Informant 8)

The pride value gained in Selamatan Laut ritual could be used as a cultural attraction in the village in Manggar by creating a strategy to promote it. Shaman of the sea also expressed the same pride because of the results of conservation efforts that have been carried out by the public welcomed by visitors. Visitor knew Manggar town with a nickname of Thousand of Coffee Shop at the island.

Historically, the area was the remains of tin mining in the era 1970s. Most of the laborers had coffee time at free time at a coffee shop in town. It was usually every monsoon, and if there was a sea accident, there must be a Selamatan Laut ritual or Buang Jong ritual. The ritual attracted some visitors from other regions. It was an interesting annual ritual that rare to be seen. Because it was a potential tourism attraction, local government and people need to build tourism facilities and local needs to learn how to handle an event.

There was an interaction between host and guest at the ritual. Selamatan Laut ritual was related to visitors and local community at Manggar. There were fundamental transformations in the ritual created the concept of host and guest, appeared when there was an interaction between two different perceptions, while the other welcoming and the other one to be welcomed [9].

Most of the visitors were local visitors that come from surrounding area of Manggar. Only a few were from out of the region, such as Jakarta and others. Visitors knew the event just because of word of mouth between them. Meanwhile, visitors from other provinces (such as Jakarta) knew the information from the local guide when they visit the island.

There was not any permanent event calendar yet about the selamatanlaut ritual until it transformed into a tourist attraction. There were interactions between each type of visitors (both local and from other provinces) albeit the interactions took only a few hours or a day visitation. Transformations in social interactions (in the ritual), were constructed between tourists, host, and stakeholders where transactions happen in the long or short term, cyclical or non-cyclical, simple or complex [33].

Perceived values were contested between host and guest during the interaction at the destination. Interaction between the host and guest is more than just a meeting between two different cultures, but there is already a desire for the host to accommodate the needs of tourists who come. Tourists want their satisfaction when their spending translated into service products (tourism). Meanwhile, hosts wanted to perceive their local wisdom through the ritual.

\section{CONCLUSION}

Transformations pattern in the case of Selamatan Laut ritual divided into functional and physical transformation, which type of system innovation was initiated by the local tourism authority. Functional transformation played dominantly, where local tourism authority set the ritual as a tourism event calendar. At the ritual event, there was a rundown in which local tourism authorities had time to give a speech on the stage and invited the local communities to participate in tourism development in the region. Shifting of policies by local tourism authorities influenced the ritual into a tourist attraction.

The physical transformation could be seen at the gallery that is used for tourism information center and displayed local handicraft, pathway nearby the beach, Sapta Pesona tourism campaign banner, and signage at the venue where the ritual held. All the built physical evidence or artifacts at the village were so-called as facilities in tourism terminology. The artifacts could change the local's identity and the environment, between tourist destination and social actors, and from a fisherman village turned into a tourist attraction.

The transformations did not impact significantly on the level of ritual authenticity. The roles of shamans who decided days and date of the three-day ceremony (Friday to Sunday) could not be replaced by any individual, organization, even by local tourism authority after had spiritual guidance from their ancestors. The artifact of jong (boat miniature) as an offering remained sacred. The low-level visitation of tourists when the ritual was held once a year recently, became the reason why the ritual kept 
in authenticity. The host and guest interacted only once a year at the ritual.

\section{ACKNOWLEDGEMENT}

The authors would like to thank the participants of the study, Tourism and Culture Authority of East Belitung Regency and local people of Manggar. The research was funded by Sekolah Tinggi Pariwisata Trisakti.

\section{REFERENCES}

[1] Burton, R. 1995. Travel geography. Pitman Publishing. London.

[2] Mitchell, R., S. Charters and J. N. Albrech. 2011. Cultural system and the wine tourism product. Annals of Tourism Research 39, 311-335.

[3] Geertz, C. 1960. Religion of Java. The University of Chicago Press. Chicago.

[4] Eisman, F. 1990. Bali: Sekala \& Niskala. Turtle Publishing. Singapore.

[5] Mancini, M. 2004. Selling destination: geography for the travel professional. Delmar Publishing. New York.

[6] Stylianou-Lambert, T. 2011. Gazing from home: cultural tourism and art museum. Annals of Tourism Research 38, 403-421.

[7] Yang, L. 2011. Ethnic tourism and cultural representation. Annals of Tourism Research 38, 561-585.

[8] Yan, L. and B. McKercher. 2013. Travel culture in Eastern Jin China (317-420 AD): the emerging of travel culture on a landscape appreciation. Annals of Tourism Research 38, 20-36.

[9] Wearing, S., D. Stevenson and T. Young. 2010. Tourist cultures: identity, place and the traveler. SAGE Publication. London.

[10] Bijker, W. and J. Law. 1992. Postscript: technology, stability, and social theory. In: Bijker, W. E. and J. Law (Eds). Shaping Technology/Building Society: Studies in Sociotechnical Change, The MIT Press. Massachusetts. 290-308.

[11] Daugstad, K. and C. Kirchengast. 2013. Authenticity and pseudo backstage of agritourism. Annals of Tourism Research 43, 170-191.

[12] Peterson, I. 1987. Qualitative Research methode for the travel and tourism industry. In: Ritchie, J. R. B. and C. R. Goeldner (Eds). Travel, Tourism and Hospitality Research. John Wiley \& Son, Inc. Canada. 433-438.
[13] Veal, A. J. 1992. Research Methode for leisure and tourism. Pitman Publishing. London.

[14] McLemann, C., B. Ritchie, L. Ruhanen and B. Moyle. 2014. An Institutional assessment of three local goverment-level tourism destination at different stages of the transformation process. Annals of Tourism Research 41, 107-118.

[15] Pudianti, A., J. Syahbana and A. Suprapti. 2016. Role of culture in rural transformation in Manding Village, Bantul, Yogyakarta, Indonesia. International Conference, Intelligent Planning Towards Smart Cities CITIES 2015. Surabaya.

[16] Hitchcock, M. and N. Stanley. 2010. Outdoor ethnography museum, tourism and nation building in Southeast Asia. In: Hitchcock, M., V. T. King and M. Parnwell (Eds). Herittage Tourism in Southeast Asia. NIAS Press. Copenhagen. 72-82.

[17] Greenwood, D. 1989. Culture by the pound: an anthropological perspective on tourism as cultural commodification. In: Smith, V. J. (Ed). Host and Guest: The Anthropology of Tourism. University of Pennsylvania Press. Philadelphia. 171-185.

[18] Richards, G. 2002. Tourism attraction system. Annals of Tourism Research 29, 1084-1064.

[19] Cheer, J., K. Reeves and J. Laing. 2013. Tourism and traditional culture: Land diving in Vanuatu. Annals of Tourism Research 43, 435-455.

[20] McKean, P. 1989. Towards a Theoritical of tourism: economic dualism and cultural involution in Bali. In: Smith, V. L. (Ed). Host and Guest: The Anthropology of Tourism. University of Pennsylvania Press. Philadelphia. 119-138.

[21] Crystal, E. 1989. Tourism in Toraja (Sulawesi, Indonesia). In: Smith, V. L. (Ed). Host and Guest: The Anthropology of Tourism. University of Pennsylvania Press. Philadelphia. 139-168.

[22] Agung, A. A. G. 2009. Tri Hita Karana. the Balinese philosophy of life. Yayasan Sekar Wangi. Jakarta.

[23] Hall, M. 2013. Framing Tourism Geography. Annals of Tourism Research 43, 601-623.

[24] Lansing, J., Y. Arby and W. Dharmiasih. 2011. The proposal to create a UNESCO World 
heritage cultural landscape: celebrating the Subaks and Water Temple of Bali. In: Putera, I. N. D. and I. G. Pitana (Eds). Bali dalam Proses Pembentukan Karakter Bangsa. Pustaka Larasan. Denpasar. 133-159.

[25] Yoshimura, M. and G. Wall. 2010. The reconstruction of Atayal identity in Wulai, Taiwan. In: Hitchcock, M., V. T. King and M. Parnwell (Eds). Heritage in Southeast Asia. NIAS Press. Copenhagen. 49-71.

[26] Pavlovich, K. 2014. A rhizomic approach to tourism destination evolution and transformation. Tourism Management 41, 18.

[27] Farsari, I. 2018. A structural approach to social representation of destination collaboration in Idre, Sweden. Annals of Tourism Research 71, 1-12.

[28] Stymeist, D. H. 1996. Transformation of Vilavilaivero in tourism. Annals of Tourism Research 23, 1-18.

[29] McGehee, N., C. Kline and W. Knollenberg. 2014. Social movement and tourism-related local action. Annals of Tourism Research 48, 140-155.

[30] Ives, C. and D. Kendal. 2014. The roles of social values in the management of ecological system. Journal of Environmental Management 144, 67-72.

[31] Widyastuti, S. 2017. Ritual communication in Muang Jong Tradition as power of tourism in Belitung Regency. Jurnal Kepariwisataan Indonesia 12, 179-202.

[32] Altinay, L., M. Sigala and V. Waligo. 2016. Social value creation through tourism enterprise. Tourism Management 54, 404417.

[33] Nash, D. 1989. Tourism as a Form of imperialism. In: Smith, V. L. (Ed). Host and Guest: The Anthropology of Tourism. University of Pennsylvania Press. Philadelphia. 37-52. 